\title{
THE YORKSHIRE MINERS AND THE 1893 LOCKOUT: THE FEATHERSTONE “MASSACRE"*
}

During the last week in July 1893, the largest industrial dispute Britain had hitherto experienced ${ }^{1}$ was initiated when over 300,000 miners in the Federated District ${ }^{2}$ stopped work. The Yorkshire miners played an important part in the lockout which was the first major trial of strength which the Miners' Federation of Great Britain had to face. The significant role of Yorkshire's pitmen in the dispute was not surprising since the colliers of the West Riding had taken a leading part in the formation of the MFGB only four years earlier, ${ }^{3}$ and the Yorkshire Miners' Association formed the cornerstone of the new organization. The stoppage occasioned extremely little violence, except in the West Riding, where a series of turbulent incidents plunged many of the mining districts into a state of anarchy and mob rule. The climactic event occurred at Featherstone when two miners were shot dead by the army. It is the aim of this article to examine the civil disorders which resulted from the lockout in Yorkshire, and to present an analysis of the Featherstone "Massacre" together with an assessment of the way in which the authorities handled the disturbances.

\footnotetext{
* I am greatly indebted to Mr D. Ashton and Mr B. Lewis, who kindly provided me with a section of their unpublished book relating to the Featherstone "Massacre". I am also grateful to Dr J. Benson for his comments on an earlier draft of this paper.

1 Twenty-one million working days were lost. H. A. Clegg, A. Fox and A. F. Thompson, A History of British Trade Unions since 1889, I (Oxford, 1964), p. 107.

${ }^{2}$ The Federated District was comprised of the following coalfields: Yorkshire, Lancashire and Cheshire, Staffordshire, Worcestershire, Cannock Chase and Shropshire, Nottinghamshire, Derbyshire, South Derbyshire and Leicestershire, Forest of Dean, Radstock, Bristol, Warwickshire, North Wales, Stirlingshire and Monmouth.

${ }^{3}$ R. P. Arnot, The Miners: A History of the Miners' Federation of Great Britain 1889-1910 (1949), pp. 91-109; cf. R. G. Neville, "The Yorkshire Miners 18811926: A Study in Labour and Social History" (Leeds Ph.D., 1974), pp. 118-47.
} 
The background to the 1893 lockout is well known. ${ }^{1}$ In short the British coal industry had once more drifted into a malaise. Coal prices began to fall in 1891, and the precipitous decline continued throughout 1892. By 1893 the price of coal was thirty-five per cent lower than it had been in $1890,{ }^{2}$ and it was clear that the colliery owners would seek to restore their profits by demanding a substantial reduction in wage rates. From the outset the MFGB and the YMA were determined to maintain the $40 \%$ advance on the 1888 wage rates which the Federation had secured between 1889 and 1890. Speaking at the YMA demonstration held at Wakefield in 1892 Benjamin Pickard (18421904), general secretary of the Association and president of the MFGB, stated defiantly: "No reduction will be submitted to. We intend to stick to what we have got. We got it by conquest and it will have to be taken away from us by conquest." 3 The employers were equally determined to enforce a reduction and on 30 June 1893 they formally demanded a $25 \%$ cut in the 1888 wage rates. ${ }^{*}$ This demand was vociferously opposed by both the Yorkshire miners and the MFGB, and at the end of July the majority of the 80,000 colliers employed in the West Riding's 253 pits were locked out, ${ }^{5}$ together with their fellow workers throughout the Federated atea.

1 For a general survey of the 1893 lockout see Arnot, op. cit., pp. 219-65. Regional studies of the dispute can be found in J. E. Williams, The Derbyshire Miners: A Study in Industrial and Social History (1962), pp. 314-43; A. R. Griffin, The Miners of Nottinghamshire: A History of the Notlinghamshire Miners' Association, I (Nottingham, 1956), pp. 87-103; id., Mining in the East Midlands 1550-1947 (1971) pp. 148-49; R. Challinor, The Lancashire and Cheshire Miners (Newcastle upon Tyne, 1972), pp. 196-200; Neville, op. cit., pp. 175237. For many years an interesting, but perhaps unnecessarily protracted, debate took place in the Bulletin of the Society for the Study of Labour History as to whether the 1893 lockout was a victory or a defeat for the miners. Shortage of space precludes a consideration of this controversy here, and I merely direct readers to the appropriate sources: A. R. Griffin, "The 1893 Lockout", in: Bulletin, Nos 5 (1962) and 25 (1972); cf. J. E. Williams, ibid., Nos 4 (1962), 5, 24 (1972) and 25; see also Neville, op. cit., pp. 227-37 and 247-65.

${ }^{2}$ F. A. Gibson, A Compilation of Statistics of the Coal Mining Industry (Cardiff, 1922), p. 157.

3 Barnsley Chronicle, 22 June 1893.

4 Some confusion existed at the time, and continues to exist, about the percentage reduction demanded by the owners, which, of course, applied to wage rates and not to earnings. The employers demanded a reduction of $25 \%$ from the 1888 rates. Since miners' wage rates in the Federated District had increased by $40 \%$ since 1888 , the demand amounted to an $18 \%$ reduction from the 1893 rates.

5 Report of the Committee Appointed to Inquire into the Circumstances Connected with the Disturbances at Featherstone on September 7, 1893 [C. 7234] (1893), qq. 22-23, p. 3, of the Minutes of Evidence, which formed a separate 
Initially the dispute was relatively peaceful, although at the beginning of August there was a disturbance at Morley Main Colliery, and several miners were brought before the courts for obstructing footpaths, assaulting the police and for various offences under the Conspiracy and Protection of Property Act of $1875 .{ }^{1}$ In addition at Middleton Colliery, near Leeds, a crowd of women and children broke the windows of two deputies' houses when it was rumoured that the men had been "filling" coal. ${ }^{2}$ Until the beginning of the fifth wetk of the stoppage, however, the Yorkshire coalfields remained generally tranquil in spite of these minor outbreaks of violence. On 2 September the Barnsley Chronicle stressed the law-abiding conduct of the colliers: "the state of affairs is the quietest ever known in such a lockout. The men are walking about spending their time as best they may, but always $[\ldots]$ quiet and orderly."3 During the following week the situation changed dramatically, and on 9 September the headlines of the same newspaper were "Rioting and damage at several collieries", "Soldiers stationed at Barnsley", "Additional police called into the district" and "The district in turmoil"."

At the beginning of September 1893, with scenes resembling those so vividly portrayed in Zola's Germinal, Yorkshire suffered a breakdown in law and order to a degree not experienced since the days of the Luddites and the Chartists. ${ }^{5}$ Civil disorders spread to many parts of the coalfield and rioting became a daily occurrence. For a short period the West Riding became an area in which an emergency situation prevailed, and which the Yorkshire police forces found themselves unable to control. As a result infantry, cavalry and Metropolitan police were drafted into the county to quash the disorders. Not even

section. Hereafter referred to as the Bowen Report and Bowen Commission, respectively.

${ }^{1}$ Bowen Commission, Appendix IV, pp. 127-28.

2 Report of Superintendent Shipley to the Chief Constable of the West Riding, 24 September 1893, Featherstone Riots Manuscripts, West Yorkshire Record Office, Wakefield.

3 Barnsley Chronicle, 2 September 1893.

4 Ibid., 9 September 1893

5 On the Luddites see J. L. and Barbara Hammond, The Skilled Labourer, 1760-1832 (1919); F. O. Darvall, Popular Disturbances and Public Order in Regency England (1934); E. J. Hobsbawm, "The Machine Breakers", in: Past \& Present, No 1 (1952), reprinted in Labouring Men (London, 1964). A popular account of Yorkshire Luddism is J. Berry, The Luddites in Yorkshire (Clapham. via Lancaster, 1970). On Chartism see R. Challinor and B. Ripley, The Miners' Association: A Trade Union in the Age of the Chartists (1968); F. C. Mather, Public Order in the Age of the Chartists (1959); id., Chartism (Historical Association, 1965); Chartist Studies, ed. by A. Briggs (1959). 
in the much larger dispute of 1926 did Yorkshire pit villages experience such turbulent times.

Of the miners' unions, only the Durham Miners' Association was stronger and better organized than the YMA at this time. ${ }^{1}$ Yorkshire colliers had gained a reputation for dogged industrial militancy and their leaders were among the most influential trade union officials in the country. These truisms do not, however, explain why Yorkshire alone experienced such violent scenes during the lockout, for the YMA leaders were essentially moderate, and reproved the miners for their law-breaking activities. Nonetheless, an indeterminate number of Yorkshire pitmen spurned the attempts of the district officials to quell the volatility of the rank and file. There is no wholly satisfactory explanation of why this was the case and why such a riotous situation evolved. The authorities, too, found it difficult to proffer an adequate interpretation of events. According to police reports, apart from the unrest at Middleton Colliery, which had involved about 2,000 people and which had easily been contained, there was nothing in particular to arouse the apprehension of the civil powers before 4 September 1893. ${ }^{2}$ On that date, however, disturbances started in Barnsley, and the troubles then spread to many other areas of the coalfield.

Nearly all the riots seem to have started at pits whtre "blacksheep"3 were working, or where coal was being moved from stockpiles, or where it was rumoured that such activities were taking place. It may well have been that after five weeks without work, the miners had become angry and embittered, for acute poverty and hardship increasingly rendered their lives more intolerable. One other possible explanation, which was later the subject of heated controversy, was that, as was customary, one quarter of the West Riding's constables were despatched to Doncaster to police the St Leger race meeting. ${ }^{4}$ With such a large number of policemen absent from the mining districts, the miners had a greater opportunity to create disturbances than hitherlo. It could have been a coincidence that the disorders began when the police were moved to Doncaster, but it appears unlikely that the practice of previous years passed entirely unnoticed by the residents of those parts of the West Riding from which the constables were drawn. The example of the first acts of violence proved contagious, and the dis-

1 The YMA was the third largest trade union in the country in 1893 . Onily the Amalgamated Society of Engineers and the Durham Miners' Association were larger. R. C. K. Ensor, England 1870-1914 (Oxford, 1936), p. 298.

2 Bowen Commission, q. 39, p. 3.

${ }^{3}$ Miners who continued working during a strike or lockout.

4 Bowen Commission, qq. 38 and 57, p. 3. The total number of policemen was 1,049 and 259 constables were sent to the races. 
orders multiplied in a chain-reaction. It may well have been that the rioting spread so rapidly because the police failed to deploy their forces speedily enough to crush the disturbances in their infancy. The West Riding police, however, who were forced to marshall all their forces, were hampered by the extensive area which they had to supervise. The Headquarters of the West Riding Constabulary was in Wakefield, which meant that the most distant constable was stationed eighty miles away. ${ }^{1}$ It is possible that all of these factors played their part in creating the disturbances.

\section{II}

It is not surprising that the troubles should have started in Barnsley, since this was the focal point of the Yorkshire coalfield and an area in which a high concentration of miners predominated. On 4 September a group of miners suspected of "filling" coal at Barrow Colliery were pursued by a large angry crowd to a public house. The mob beat tin cans, shouted insults and smashed every window in the building before the police arrived in strength to disperse the demonstration. ${ }^{2}$ Thereafter the disorders quickly spread over a wide geographical area stretching approximately from Barnsley to Rotherham, Leeds and Dewsbury. Collieries where it was known, or rumoured, that coal was being loaded into railway wagons were subjected to attacks by crowds of miners. The size of the marauding mobs was frequently large, and many men menacingly carried bludgeons and other arms. On 5 September, for example, at Waterloo Colliery near Leeds 5,000 men converged on the pit to prevent deputies from going underground, ${ }^{3}$ and the same day a mob of over 1,000 converged on Hoyland Silkstone Colliery, near Barnsley. ${ }^{4}$ At several mines there were acts of violence, destruction and arson, which soon assumed a stereotyped form. Colliery managers' offices were wrecked, windows smashed, coal wagons derailed and ignited, books and papers scattered over pit yards, and colliery officials and blacklegs assaulted and intimidated. Incidents of this nature occurred at Manvers Main on 4 September, and at Rylands Main and Rockingham Colliery the following day, for example. ${ }^{5}$

1 Ibid., q. 11, p. 2.

2 Barnsley Chronicle, 9 September 1893.

${ }^{3}$ Bowen Commission, Appendix III, p. 125; Yorkshire Evening Post, 19 February 1912; G. S. Hudson, The Aberford Railway and the History of the Garforth Collieries (Newton Abbott, 1971), p. 139.

4 Bowen Commission, Appendix III, p. 125; Barnsley Chronicle, 9 September 1893.

5 Neville, op. cit., pp. $186 \mathrm{ff}$. 
The mobs were so large that the police were often powerless to make arrests. At Rockingham Colliery six constables arrived at the height of the disturbances and attempted to arrest the first six rioters they encountered. The mob reacted violently and bombarded the police so severely with stones that the constables were compelled to retreat without their prisoners. Eventually, after two hours of unrestricted destruction, the rioters set fire to the coal stack and the stables. ${ }^{1}$ At Waterloo Main a Police Superintendent admitted that his men had been unable to take any effective action: "No arrests were made, if there had been, no doubt worse consequences would have ensued." 2 In addition to attacks on collieries there were numerous cases of crowds of colliers consisting of several hundred men and youths, travelling from place to place demanding interviews with colliery managers to obtain promises that no loading of coal would take place. Shopkeepers in some areas took the precaution of boarding up their windows, threatening language was used by groups of miners to inhabitants throughout the district, people were robbed and intimidated, and "the public generally in the west and south-west of the West Riding" were placed "in a state of great terror and alarm". ${ }^{3}$

By 5 September it was clear to the Home Office and the Chief Constable of the West Riding that the situation was moving swiftly out of control. Large reinforcements were required immediately, and were accordingly rushed into Yorkshire. Troops and police were drafted into the county from other regions, and soldiers were stationed in the mining districts. The accompanying statistics reveal a formidable military presence in Yorkshire's mining communities in addition to the 400 constables from the Metropolitan Constabulary and other police reinforcements.

Meanwhile, Benjamin Pickard and the other YMA officials were appalled by the campaign of destruction and violence that certain of their members were perpetrating. The union completely disassociated itself from the disturbances and implored all miners to act peacefully. In a YMA circular dated 4 September 1893 Pickard stated as follows:

"Violence in any form will not help us to win this battle. Every member is urged to view this struggle from the moral, social and pecuniary point of view, and not to lend himself in the smallest

${ }^{1}$ Ibid., p. 190; Whitham's Almanack, 1893, pp. 21-23.

2 Report of Superintendent Joseph Stansfield, Number 12 Division, Leeds, to the Chief Constable, 5 September 1893, Featherstone Riots Manuscripts.

${ }^{3}$ Bowen Commission, Appendix III, p. 125; Barnsley Chronicle, 9 September 1893. 
Return of Troops Employed in aid of Civil Power in Yorkshire on September 6th, 7th and 8th, 1893

\begin{tabular}{|c|c|c|c|}
\hline Date & Place & Cavalry & Infantry \\
\hline 6 Sept. & $\begin{array}{l}\text { Thorncliffe } \\
\text { Chapeltown } \\
\text { Barnsley }\end{array}$ & 50 6th Dragoon Guards & 60 Dublin Fusiliers \\
\hline 7 Sept. & $\begin{array}{l}\text { Wakcfield } \\
\text { Dewsbury } \\
\text { Rotherham }\end{array}$ & $\begin{array}{l}1 \text { Troop King's Dragoon } \\
\text { Guards } \\
1 \text { Troop King's Dragoon } \\
\text { Guards } \\
50 \text { King's Dragoon Guards } \\
20 \text { 6th Dragoon Guards }\end{array}$ & \\
\hline & $\begin{array}{l}\text { Barnsley \& } \\
\text { Collieries }\end{array}$ & 50 6th Dragoon Guards & 100 Royal Scots \\
\hline & $\begin{array}{l}\text { Wombwell } \\
\text { Morley } \\
\text { Featherstone }\end{array}$ & & $\begin{array}{l}50 \text { Dublin Fusiliers } \\
40 \text { South Staffordshire } \\
28 \text { South Staffordshire } \\
7651 / 65 \text { Depots }\end{array}$ \\
\hline & $\begin{array}{l}\text { Nostell } \\
\text { Thorncliffe } \\
\text { Chapeltown }\end{array}$ & & $\begin{array}{l}2551 / 65 \text { Depots } \\
60 \text { Dublin Fusiliers }\end{array}$ \\
\hline & $\begin{array}{l}\text { Broughton } \\
\text { Lane }\end{array}$ & 23 RA (Mounted) & \\
\hline
\end{tabular}

8 Sept. Situation as on 7 Sept., 50 Northamptonshire (Infantry) moving into Wakefield, party of 50 Dublin Fusiliers to Neepsend, and 20 6th Dragoon Guards out of Rotherham, plus:

Garforth

Castleford

Sheffield
50 Suffolk

50 South Staffordshire

Adapted from Bowen Commission, Appendix II, p. 124. A troop usuallv consisted of 60 cavalrymen with two lieutenants and a captain.

degree to violence of any sort of condition. The man who uses violence at this critical period is the greatest enemy of the cause and would be doing the cause of the Association a tremendous wrong."1

Nonetheless, Pickard's words were ignored by many miners, and the colliery owners became understandably anxious about the security of their property.

1 YMA Minutes, 4 September 1893. In the possession of the National Union of Mineworkers, Yorkshire Area, Miners' Offices, Barnsley. 
The Yorkshire coalfields were now alive with troop movements, marching mobs, mass meetings of colliers and wild rumours of imminent attacks on various pits. Crowds of people turned out in the mining villages to see the red-coated soldiers who requisitioned entire collieries and established temporary barracks in the pit yards at, for example, Darfield Main Collicry, Woolley and Pilley pits and at Thorncliffe lronworks, the property of Newton Chambers Colliery Co. Ltd. ${ }^{1}$ In many places outdoor meetings of miness resolved categorically not to accept any reduction in wages, and urged colliery managers to prevent any further coal being transported from the pits until the dispute had been resolved. At some collieries, however, coal continued to be loaded, and on 6 and 7 September there were disturbances, some serious, at Simon Wood, North Main, Bruntcliffe, Roche, Carlinghow, White Lee, Ravels, Hoyland Silkstone (Pumping Station), Hemingfield and Wath Main. ${ }^{2}$ The police and 800 troops had an arduous and hazardous task and altogether 127 people were arrested. The hard-pressed security forces also discovered that they had an additional problem to contend with: gangs of colliers were blocking some of the major roads and demanding toll money from travellers. ${ }^{3}$ This practice appears to have begun on the Barnsley to Doncaster road before spreading elsewhere, and on 6 September a Police Superintendent and a JP returning from a riot at Elsecar Colliery were attacked in Hoyland. They were beat about the head and forced to pay a toll. As much as a sovereign was paid for a trip from Barnsley to Hoyland according to one press report. ${ }^{4}$

1 Whitham's Almanack, 1893, p. 26.

2 For a detailed account of these disturbances see Neville, op. cit., pp. 191ff.; Whitham's Almanack, 1893, pp. 17-27. A popular but valuable account of the rioting is to be found in the Yorkshire Evening Post, 9, 10, 11 and 12 December 1974, viz., D. Naylor, "The Darkest Summer". For a voluminous collection of newspaper cuttings relating to the disorders see Ackton Hall and Featherstone Collieries Manusciipts, Goodchild Loan Manuscripts, Wakefield Metropolitan District Archives, and Newton Chambers and Co. Ltd. Manuscripts, Sheffield Central Library. The total amount of claims for compensation under the Riot Damages Act of 1886 by Yorkshire colliery owners from August to October 1893 came to $£ 11,332$, and the claim put forward by the Wath Main Colliery, Co. Ltd. for the damage at their pit on 6 September amounted alone to $£ 7,180$. See list of claims for compensation under the Riot Damages Act, 1886, in respect of damage arising out of colliery riots in the West Riding in August, September and October 1893, Featherstone Riots Manuscripts.

${ }^{3}$ See, for example, Earl Fitzwilliam to his mother in Ireland, 9 September 1893 , Fitzwilliam Papers, Wentworth Woodhouse Muniments, Sheffield Central Library.

- Barnsley Chronicle, 9 September 1893. 
It is not necessary to encumber these pages with a detailed account of the complex events which preceded the Featherstone disorders, ${ }^{1}$ but a brief survey is necessary to facilitate a satisfactory analysis of the "Massacre". The local police regarded Featherstone as one of the least likely places where rioting could be expected, and two of the three constables stationed in the town were sent to Doncaster to assist in the supervision of the races. ${ }^{2}$ Initially the police were correct in their judgement and there were no incidents in Featherstone to cause alarm. ${ }^{3}$ On 5 September, however, a crowd visited Ackton Hall Colliery and peacefully prevented the loading of "smudge" (small coal or slack). The following day the colliery manager, A. J. Holiday, agreed to stop loading slack temporarily, but when it was alleged that "filling" had been resumed a mob returned to the mine and overturned six fully loaded railway wagons. Holiday was convinced that the colliery was threatened with destruction and travelled to Pontefract to appeal to the police for help. The latter informed him that no officers were available, and Holiday was shown a dozen telegrams from colliery owners begging police protection for their property. During Holiday's absence another crowd had overturned a further seven wagons. ${ }^{4}$ As a consequence Holiday journeyed to Wakefield to see the Chief Constable, where he met Lord St Oswald, who was also seeking police protection for his colliery at Nostell. Chief Constable Russell informed the two men that because of the large contingent of police at the Doncaster races he had no men available, and all he could offer was military aid. This offer was accepted, and after a delay of several hours 50 infantry were obtained from Bradford. ${ }^{5}$ Half the soldiers were sent to Nostell, and eventually 26 troops, a police inspector and two constables arrived at Featherstone. All attempts to secure a magistrate had failed and the troops lodged themselves in the colliery engine house to await the arrival of a JP. It should be emphasized that when the soldiers arrived at Ackton Hall Colliery there was "no crowd or disorder" except for about twenty men who derisively jeered the troops. ${ }^{6}$

1 For a more thorough account see Neveille, op. cit., pp. 197-205.

2 The fact that the colliery was left unprotected is surprising since it had recently been the subject of considerable capital investment. Wakefield Express, 8 September 1893.

${ }^{3}$ Bowen Report, p. 3.

4 Ibid., p. 2.

5 Ibid., p. 4.

Ibid. 
News of the arrival of the troops spread rapidly and created an air of excitement in the local community. Crowds of people, some armed with cudgels, began to assemble in the streets and the concourse gradually increased in size. A deputation from the crowd demanded that the troops be removed, and when Holiday intimated that this was not within his power he and the police inspector were pelted with stones. ${ }^{1}$ The colliery was surrounded, the engine house stoned, all the windows in the building were broken and the crowd taunted the frightened soldiers. One rioter tried, unsuccessfully, to ignite the engine house in order to flush out the troops. ${ }^{2}$ Captain Barker, the officer leading the soldiers, with great courage emerged from the building to conclude a bargain with the rioters. He offered to withdraw his men from the colliery premises on the understanding that the crowd dispersed without causing any further damage. ${ }^{3}$ The mob agreed, and Barker led his troops like a squad of prisoners through the surging crowd back to the railway station.

Word of the troops' arrival had spread beyond the confines of Featherstone, and furthermore fires had been started, which illuminated the whole area. The fires could be clearly seen in Sharlston, Normanton, Lascoe, Castleford and Pontefract, and people made their way to the colliery, their curiosity aroused by the conflagrations. ${ }^{4}$ The trains from Pontefract were crowded with sightseers throughout the latter part of the evening. At the Home Office Inquiry which was later held into the riot at Featherstone, there was considerable evidence which suggested that many people deliberately went to Ackton Hall Colliery in order to participate in disturbances. ${ }^{5}$

At this juncture the long-awaited JP finally arrived in the person of Bernard Hartley. In view of the fact that the violence was escalating and that the crowd was not dispersing it was determined that the troops should return to the colliery premises. Hartley and Holiday, accompanied by Inspector Corden, advanced into the pit yard with the troops in close order behind them. ${ }^{6}$ With tremendous patience Hartley tried repeatedly to persuade the crowd to go home peacefully so that he would not have to read the Riot Act. All his efforts failed, and he made a final plea to those with intelligence to leave directly as he was about to read the Riot Act, whereupon the tioops would be empowered

1 Ibid., p. 5.

2 Bowen Commission, q. 1252, p. 35.

3 Ibid., qq. 1253-54, p. 35.

4 Wakefield Express, 8 September 1893.

5 Bowen Commission, qq. 1114-27, p. 32.

- D. Ashton and B. Lewis, final draft of an unpublished book concerning the Featherstone "Massacre". 
to take action. It was now dark, and Hartley read the Act by the light of a lantern in relative silence, but as soon as he had finished fusillades of stones were hurled in his direction. ${ }^{1}$

By this time Ackton Hall Colliery was clearly a scene of tremendous and uncontrolled confusion. ${ }^{2}$ The troops had sustained several injuries as a result of stone throwing, and Barker was of the opinion that his men should tolerate no more. He ordered his men to advance towards the crowd with fixed bayonets. ${ }^{3}$ The mob temporarily retreated, but proceeded to spread themselves out and slowly surround the soldiets. Hartley then gave Barker written permission to open fire, and added verbally that blank cartridges should be used if possible, but the Captain informed him that the troops had not been supplied with blanks as it was against army regulations to use anything but live ammunition in the prevailing circumstances. ${ }^{4}$ Two soldiers fired at the "ground line" with the intention of injuring as many people as possible by the ricochets of the bullets. After a momentary silence the crowd, under the misapprehension that only blanks had been fired, advanced towards the soldiers and swept into the pit premises throwing volleys of stones. Five minutes passed and then the second order to fire was given. This time eight soldiers fired sixteen rounds of ammunition in sectioned volleys, and the noise and stone-throwing stopped instantly, for it was apparent that people had been hit. ${ }^{5}$ Two men, James Gibbs, a miner from Loscoe, and James A. Duggan, an Ackton Hall Colliery employee, were severely wounded and later died as a result of their injuries, and approximately a dozen other people received wounds of varying severity. ${ }^{6}$ Remarkably, one man standing on the footpath, outside Featherstone Main Colliery, almost a quarter of a mile away, was injured by a bullet in the thigh.7 After the soldiers had fired the crowd $^{8}$ did not disperse, and when ninety soldiers arrived from Ponte-

1 Wakefield Express, 8 September 1893.

2 Ashton and Lewis, op. cit.

3 Bowen Commission, q. 1302, p. 36.

4 Ibid., qq. 1312-13, p. 36.

5 Wakefield Express, 8 September 1893.

6 There were reports in the Daily Chronicle and Manchester Guardian, 9 September 1893, that a third man called Tomlinson had died, and the Sheffield Telegraph, 9 September 1893, contended that a third man called Perkins had died. Ashton and Lewis, op. cit. In the official evidence, however, it was reported that only two men were killed.

7 Bowen Commission, q. 1422, p. 39.

8 No accurate statistics for the size of the crowd are available, but one corporal estimated that there were between 10,000 and 12,000 people present at the colliery. This may have been an exaggeration, but the official figure of 3,000 was probably a low estimate. 
fract Barracks two hours later they too were pelted with stones. Only in the early hours of the morning did the rioters begin to trickle home.

Not surprisingly, the deaths of the two men, and the injuries received by other people, generated bitter tension and anger amongst the Yorkshire miners. At the Council meeting on 13 September 1893 the YMA, though proscribing violence and unlawful acts, also condemned "the action of the magistrates in calling in extra police and soldiery whilst at the same time they allowed, as is alleged, about 600 police to be drafted to Doncaster during the race week to protect the general public". The union also called for a public inquiry into the "so called riot at Ackton Hall Colliery". ${ }^{1}$ Such was the bitterness in Featherstone that Holiday was kept under military and police protection; troops guarded Ackton Hall Colliery and a flag was hung from the pit shaft to denote military occupation. ${ }^{2}$

The fury of many miners was exacerbated by the conflicting verdicts of the inquests on the two dead men. Duggan's inquest was held in the calm of Wakefield but that of Gibbs took place in Featherstone, which was still seething with resentment. ${ }^{3}$ Different coroners and juries were used, and markedly different verdicts were returned. The Wakefield jury escaped the throngs of furious miners who besieged the hotel in Featherstone where Gibbs's inquest took place, and returned a verdict of "Justifiable Homicide" without difficulty." At Featherstone the atmosphere was charged with emotion and the verdict was not so easily reached, nor determined so concisely. The coroner at Featherstone was confronted with a jury which frequently appeared to know more about the events of the 7 September than the witnesses, and jurors were repeatedly cautioned for asking improper questions and arguing with witnesses. Moreover, the cross-examination of the solicitor representing the relatives of the deceased brought the proceedings close to being a trial of Holiday and the authorities, rather than a simple enquiry into how Gibbs met his death. ${ }^{5}$ The jury refused to declare that Gibbs's death was either legal or justifiable, but stressed that the dead man had been a peaceful character who had taken no part in any riotous events. They condemned the removal of the police to the Doncaster races, emphasizing that if policemen had been used at Ackton Hall Colliery the tragedy could have been averted. ${ }^{6}$ In a rider

1 YMA Minutes, 13 September 1893.

${ }^{2}$ Leeds Express, 14 September 1893.

${ }^{3}$ Ashton and Lewis, op. cit.

4 Ibid.

${ }^{5}$ Ibid.

- An Inquisition taken at Featherstone in the County of York on view of the body of James Gibbs, dated 9, 12 and 13 September 1893, Featherstone Riots Manuscripts. 
to the verdict it was stated that "the jury deeply regret that such extreme measures were adopted by the authorities". ${ }^{1}$

\section{IV}

The national press gave full coverage to what they called the Featherstone "Massacre", and on 20 September 1893 the subject was raised in the House of Commons. ${ }^{2}$ In view of the public outcry, and the two opposing coroner's verdicts, the Home Secretary, Herbert Asquith, was almost obliged to establish a commission of inquiry. The Bowen Commission, consisting of Lord Bowen, ${ }^{3}$ Sir Albert K. Rollitt and Richard B. Haldane, ${ }^{4}$ was duly convened, and sat at the West Riding Court, Wakefield, sifting through vast quantities of written and oral evidence. The Bowen Report, which was published on 6 December 1893 , was notable to the contemporary public for exonerating the magistrates, officers and troops, and to lawyers for formulating with great precision the respective duties of the civil and military authorities at times of public disorder. Retrospectively, however, the riot at Featherstone, the shootings and the Commission of Inquiry which met afterwards raise many questionable issues. Not only did the authorities miscalculate how potentially dangerous the Featherstone area was, but after belatedly realizing their error of judgement they proceeded to handle the situation in an arguably incompetent way. From start to finish the "Featherstone affair" was dogged by a series of unfortunate, and in some cases, inexplicable anomalies, which make the exonerating statements contained in the Bowen Report appear rather incongruous.

Many key people who would normally have been available in the Yorkshire coalfields were absent, and this proved to be a factor of some importance. The YMA district officials, with the exception of John Frith, ${ }^{\mathbf{5}}$ were attending a Trade Union Congress at Belfast at the time of the agitation. Although the rioters had previously ignored the disapproving YMA circulars which urged the cessation of violence, John Frith, the union's financial secretary, had confronted several mobs personally and persuaded them to peacefully disperse. His industrious exhortations did not go unnoticed, and the Barnsley

1 Ibid.

${ }^{2}$ House of Commons Debates, Fourth Series, XVII, cc. 1719-29.

${ }^{3}$ Lord Charles Synge Christopher Bowen, 1835-94, one of the most distinguished nineteenth-century legal minds.

4 Richard Burdon Haldane, 1856-1928.

5 John Frith, 1837-1904, secretary of the South Yorkshire Miners' Association, 1876-1881, and financial secretary of the YMA, 1881-1904. 
Chronicle remarked: "Mr. Frith did a large amount of good by his sound practical advice, and through his means [sic] several probable disturbances were averted. On several occasions late in the evening he persuaded large concourses of people to go home quietly and orderly:"1 If Ben Pickard and the other officials had been present in Yorkshire, they would have effectively helped Frith in encouraging lawful behaviour and as a result the rioting at Ackton Hall Colliery might have been limited or prevented.

In addition, the Chief Constable of the West Riding had only returned from his vacation on 6 September, ${ }^{2}$ and therefore was not fully familiar with the scale and gravity of the situation with which he was expected to deal. Moreover, as indicated above, a quarter of the West Riding Constabulary were in Doncaster engaged in arresting pick-pockets and other duties instead of being deployed in the mining villages. In the House of Commons Asquith dismissed this point as irrelevant: "Gentlemen, as to the withdrawal of police for the Doncaster races, they would have been in any case insufficient to cope with this suddenly arising emergency." 3 It was quite probable, however, that a large body of police could have handled the situation more satisfactorily than a mere twenty-six soldiers, and in the first instance it was the non-availability of police which led to troops being despatched to Featherstone. The court of inquiry, although admitting that it was easy to be "wise after the event" and that "a very large police force" 4 would have been needed to protect Ackton Hall Colliery also stated that if sufficient police had been available they might well have been able to cope with the stuation. ${ }^{5}$

Moreover, there was a long delay before troops arrived at Featherstone. When Captain Barker reached Ackton Hall Colliery, seven hours had elapsed since the manager had first requested assistance, and by this time the crowd had left the premises and there was no sign of a disturbance. ${ }^{6}$ The arrival of red-coats in a small town like Featherstone was a novel sensation, and news of the troops' arrival soon brought the local inhabitants out of their houses. ${ }^{7}$ The news of the arrival of the troops spread rapidly through the small mining villages in the Featherstone district, and paradoxically the arrival of the military had exactly

1 Barnsley Chronicle, 9 September 1893.

2 Bowen Commission, qq. $350-58$, p. 13.

${ }^{3}$ House of Commons Debates, Fourth Series, XVII, c. 1719.

${ }^{4}$ Bowen Report, p. 9.

5 Ibid.

6 Bowen Commission, qq. 1221-23, p. 34.

7 See J. J. Terrett, The Right Hon. H. H. Asquith, M.P., and the Featherstone Massacre (Social Democratic Federation, 1906), p. 11 (Leeds City Library). 
the opposite result to that which was intended. Large numbers of people travelled to the colliery purely to see the soldiers, and if troops had not been sent to the mine the "Massacre" would have been avoided.

Additionally, the size of the military contingent was too small to quell the disorders without resorting to the use of firearms. Barker had left Bradford with fifty-three men, but the Deputy Chief Constable, partly on the insistence of Lord St Oswald, demanded that the troops be divided. ${ }^{1}$ It was only with great reluctance that Barker consented to this demand and ordered twenty-five of his men under a lieutenant to proceed to Nostell Colliery. ${ }^{2}$ Soldiers could only have been used effectively at Featherstone if they had been present in large enough numbers to make the local populace frightened, or at least wary. As it was, Barker's pitiful band was forced to hide in the engine house. The troops did not command the respect of the crowd that gathered, and indeed before the fatal shots were fired the mob treated the soldiers with derision. ${ }^{3}$ Moreover, as Ashton and Lewis have observed, an absurd decision was taken to transport an inadequate body of soldiers all the way from Bradford when a much stronger military force was available only two miles away from the colliery.

"Given that troops were required to assist the police and given that Barker's original force of 53 men was too small to be divided, why did no one take the step of sending to Featherstone troops from the neighbouring barracks at Pontefract? [...] As a result, the curious situation arose of a small body of soldiers surrounded, and at one point positively besieged, by a mob of rioters not two miles from a barracks with an establishment capable of despatching three officers and 76 men".4

If Pontefract barracks had been consulted that morning, soldiers in force could have been rushed to the colliery whilst the rioting was in progress. The pattern of events might then have been similar to that which had occurred at Wath Main, when the rioters caught red-handed by the army had fled from the scene. ${ }^{5}$ It is surprising that this point was not brought out at the Inquiry, either by the Commissioners or by the legal representatives.

Other mistakes were also made. For example, Barker was despatched to Featherstone as a complete stranger to the area, and without a JP

1 Bowen Commission, q. 1211, p. 34.

2 Ibid.

3 Ashton and Lewis, op. cit.

4 Ibid.

5 Neville, op. cit., pp. 194-95. 
to assist him in the performance of his duty. The fact that Bernard Hartley, JP, did not arrive at the colliery until four hours after Barker, illustrates, to some extent, the lack of organization exhibited by the authorities. The Bowen Committee commented:

"It is probable that if a magistrate had been present the troops would never have withdrawn from the colliery premises to the station, and the conflict with the crowd, if any had been necessary, might have occurred during daylight and not after dark."1

The report recommended that there should be a rota of experienced JP's ready to act in their magisterial capacity in the event of any emergency. ${ }^{2}$

Barker was also under the erroneous impression that he was powerless to take any action in a riotous situation unless a magistrate was present. The Official Manual of Military Law did expressly prohibit an officer from ordering his troops to fire, "unless distinctly required to do so by the magistrates". There was an exception, however, and as Ashton and Lewis discovered this was clearly indicated in a footnote to the Home Office file containing a copy of Barker's report to the War Office, viz., "He [Barker] seems to have thought that he could do nothing without a magistrate. This is certainly not the law. When he saw actual outrages being committed - even arson - he could certainly have acted on his own responsibility." 3 The Commission endorsed this view after it had benefited from the authoritative opinion of Adjutant-General Sir Redvers Henry Buller (1839-1908), who indirectly accused Barker of failing to perform his duty. ${ }^{4}$ Although there was no suggestion of cowardice on Barker's part the Bowen Report contained an implicit reprimand of the Captain's conduct.

Finally, a further questionable matter concerning the handling of the riot relates to the military regulations and procedures the army was to follow during civil disturbances. The troops were not allowed to use blanks, and indeed were only issued with live ammunition. It was no part of the regulations that the opening shots were to be fired over the heads of the crowd as a warning, and indeed the regulations stated that soldiers were to fire at the "ground line". The effect of this order was that bullets were fired at a point on the ground some small distance in front of the crowd so that they would ricochet upward and hit people's legs before going up to their bodies. ${ }^{5}$ The rifles were sighted

'Bowen Report, p. 9.

2 Ibid.

3 Ashton and Lewis, op. cit.

4 Bowen Commission, q. 5312, p. 121.

5 Ashton and Lewis, op. cit. 
for 2,900 yards, and at 400 yards a bullet would penetrate thirty-five to thirty-seven inches of green elm. ${ }^{1}$ To cite another example, at short range a bullet would pass through six people provided that it was not stopped by bone. ${ }^{2}$ These regulations precluded aimed shots, and consequently all firing was completely indiscriminate. Hence two innocent spectators were killed and a man a quarter of a mile away was injured. In thickly populated districts and against large crowds such regulations were excessively inappropriate. Sir Redvers Buller, later to distinguish himself in the Boer War, was opposed to the use of less lethal ammunition and to the use of pistols, ${ }^{3}$ but the Commission, although respecting his views, recommended an investigation by the military authorities into the possibility of using less dangerous arms and ammunition in the case of civil agitation. ${ }^{4}$

On the eve of the "Liberal Landslide" election of 1906, J. J. Terrett, under the auspices of the Social Democratic Federation, issued a pamphlet bitterly attacking "assassin Asquith" and the "Whitewashing Commission". ${ }^{5}$ Terrett described the Featherstone tribunal as

"A packed Commission, composed of law-lord Bowen, learned brother Haldane, and that good, honest, but utterly unimaginative and completely bourgeois Conservative, Sir Albert Rollit [...] Labour members were religiously excluded - they might have brought out a minority report."6

It is true that the composition of the Commission was generally welcomed by all sections of the press, and that Haldane was a radical Liberal, whilst Bowen's sympathies lay with the Liberals and Rollit could be described as a "progressive" Conservative. ${ }^{7}$ Nonetheless Terrett's judgement was justifiable. Asquith endured considerable personal unpopularity as a result of the events at Featherstone, and if a minority report had been published, or if the Commission had upheld the verdict of the Featherstone Coroner's Jury, he would have been placed in an uncomfortable political position. Haldane was the only "left-wing" Commissioner and he also happened to be one of Asquith's closest friends; moreover, Bowen himself was closely acquainted with the Home Secretary and had been his master in 1876 when the young

1 Bowen Commission, qq. 1421-23, p. 39.

2 Ibid., q. 1424, p. 39.

${ }^{3}$ Ibid., qq. 5316-18, p. 122.

4 I have been unable to establish whether or not the War Office later examined this question.

5 Terrett, op. cit., pp. 7 and 20.

I Ibid., pp. 18-19.

7 Ashton and Lewis, op. cit. 
Asquith, then preparing for the bar, had worked under him in chambers. ${ }^{1}$ As Asquith's biographer has noted, "Had Asquith not been so 'cassant' he might have chosen a less intellectually distinguished and more politically appeasing Commision."2

In some ways the terms of reference of the Commission were unsatisfactory. It was not a royal commission and its powers were therefore limited - witnesses did not present evidence under oath, for example. Also the scope of the Inquiry could be judged to be too narrow. Lord Bowen made it clear that the Commission would concern itself purely with those facts directly concerned with the disorders at Featherstone on 7 September. A wide ranging inquiry into the state of the coalfield and disturbances elsewhere was strictly prohibited, as were leading questions relating to the government's direction of the military. The Featherstone "Massacre" could not be viewed satisfactorily in isolation from the turbulent situation that prevailed throughout the West Riding, and these circumscriptions must have hindered the work of the Commissioners.

The political manifestations of the "Massacre" were most harmful to Herbert Asquith and the Liberal Party. In some Yorkshire mining villages Asquith was known thereafter as "Bloody Asquith" or "Featherstone Asquith", and shortly after the shootings an effigy of the Home Secretary surmounted with Death's head and cross bones was carried to Trafalgar Square, where disturbances took place. ${ }^{3}$ The affair was detrimental to the Liberal Party's cause at a critical time when the nascent ILP and other socialist groups were gradually expanding. Widespread indignation at the shootings was voiced by people of all shades of political opirion throughout the country, and a particularly hostile condemnation came from the various sections of the labour movement. Asquith and the Liberal Party were denounced by the SDF, by the ILP and Keir Hardie, and by Cunninghame Graham; 4 and Sam Woods ${ }^{5}$ and other MPs delivered several scathing antiAsquith speeches. "Featherstone" pursued Asquith throughout the middle years of his career and earned him a measure of working-class unpopularity, much as "Tonypandy" did Winston Churchill nearly a generation later. ${ }^{7}$

1 R. Jenkins, Asquith (1964), pp. 27-28.

2 Ibid., p. 74.

3 Terrett, op. cit., p. 17.

4 Robert Bontine Cunninghame Graham, 1852-1936.

5 Samuel Woods, 1846-1915, Vice-President of the MFGB, 1889-1909.

6 Terrett, op. cit., p. 17.

7 Jenkins, op. cit., p. 74. 
The depth of local feeling aroused by the Featherstone disturbances and the deaths of the two miners was considerable. As a result there was an absence of prosecutions following the "Massacre". The police realized that to have arrested miners for rioting at Ackton Hall, after the event, would have caused a complete breakdown in relations between the police and the local inhabitants, and would only have served to rekindle the smouldering grievances, thus exacerbating a situation that was gradually quietening. The YMA officials were incensed, but nonetheless urged their members to act peacefully. The disgust that was felt by the YMA because of the shootings was voiced by Ben Pickard on his arrival home from Belfast.

"it appears to me that although they [the army] could not beat the Zulus they seem to be desirous of showing that they can shoot down colliers. When an officer admits before a Coroner's Court that he intended every shot to have effect, although one of the witnesses declared that at the time the shots were fired there was no rioting and had not been for some time $[\ldots]$ that in my judgement must constitute a serious offence." 1

The Bowen Report, which rejected the evidence to which Pickard referred and exculpated the security forces, was a bitter pill for the YMA to swallow.

The Featherstone disorders proved to be the last of the major disturbances in the West Riding. The example of "Featherstone" had two main results. Throughout the mining communities it had a sobering effect, although ironically to the colliery owners it was a sign of further disorders to come. Rumours of impending riots and destruction were prolific, and letters and telegrams requesting military and police assistance flooded into the Chief Constable at Wakefield. Most of the letters were written in the same alarmist and demanding vein, illustrated by the following correspondence by T. R. Gainsford, Managing Director of the Sheffield Coal Company Ltd. He wrote to the Chief Constable demanding

"a definite reply from you as to what course we should take to obtain protection from you in case of need. I beg your reply by telegram early as possible in the morning saying to whom and in what form we should communicate in case of any expected need, and in how short a time after receipt of a message effectual protection of police and military by swift conveyance may be

1 Barnsley Chronicle, 16 September 1893. 
here. Of course if any damage be done, claim for compensation will be insisted upon for the late proceedings have been very disgraceful. And I think I ought to mention that I am told a large Miners' meeting is to be held tomorrow (Saturday) forenoon at Darnall just within the Borough of Sheffield, but close on the borders of Handsworth Parish, and I think you should have that side of the Parish watched all day.

P.S. I must add that in my opinion you ought to have the district well and regularly patrolled every day by military or mounted police." 1

Panic spread rapidly among the employers during early September and Earl Fitzwilliam, the prominent South Yorkshire colliery owner, took quite desperate measures to protect himself and his family. After receiving news from a "reliable source" that his residence was to be attacked by 1,000 miners at 4 a.m. he hired 80 vigilantes to guard his land, boarded up the ground floor windows and retreated to the first tloor of the building. Not until 16 September did he consider it safe to come out of his house and by this time the disorders had died down. ${ }^{2}$ The attack had never materialized and the rumour was typical of those which circulated in the homes of the well to do at this time.

After 7 September the authorities, wishing to take no further risks, drafted further military reinforcements into the West Riding, Derbyshire and Nottinghamshire from Colchester and Norwich. ${ }^{3}$ Proclamations were also issued warning miners, and the general public, that law-breaking and riotous behaviour would not be tolerated, and would be ruthlessly extirpated. ${ }^{4}$ Such strong warning had the desired effect, and there was no wholesale destruction of property as there had been in the previous week. Small gangs of miners continued to terrorize people, however, and highway robbery was still prevalent as the numerous surviving letters to the Chief Constable bear witness. ${ }^{5}$

The great tragedy of the 1893 lockout, and the disputes in the coal industry in 1912, 1921 and 1926, was the human misery experienced by so many miners and their families. The situation became more distressing in Yorkshire after 30 September 1893 when the YMA announced that its relief fund was bankrupt. Thereafter living con-

1 T. R. Gainsford to Captain Russell, the Chief Constable of the West Riding, 8 September 1893, Featherstone Riots Manuscripts.

2 Earl Fitzwilliam to his mother, 9 and 15 September 1893, Fitzwilliam Papers.

${ }^{3}$ Barnsley Chronicle, 16 September 1893.

4 Ibid.

${ }^{5}$ Miscellaneous letters to the Chief Constable of the West Riding, Featherstone Riots Manuscripts. 
ditions continually deteriorated and soup kitchens were in evidence in many parts of the coalfields. Throughout the West Riding a network of relief committees and sub-committees was established and local clergy and schoolmasters, publicans, the Salvation Army, temperance societies and the press lent assistance. ${ }^{1}$ Although these agencies helped to reduce hardship, for thousands of families the acrimonious dispute of 1893 resulted in appalling hunger and poverty. Thus the return to work at pre-stoppage rates, which was agreed to on 17 November after the intervention of Lord Rosebery, who acted as an independent arbitrator, was generally greeted with considerable enthusiasm in the pit villages.

\section{VI}

The most striking feature of the 1893 lockout in Yorkshire was the extensive and violent civil strife, which caused widespread alarm and was unique to the region. It may be concluded that the Featherstone "massacre", which effectively terminated the outrages, can not simply be dismissed as an incident which the miners brought upon themselves. A series of unfortunate faux pas and a degree of bungling by the authorities also played an important part in the events which led to the deaths of the two colliers. The Featherstone "Massacre" was one of the rare occasions since the slaughter at Peterloo in 1819 when the army has fired on British workers, and as such forms one of the most notable chapters in the history of the miners. The disturbing events at Ackton Hall Colliery in 1893 were remembered for many years by Yorkshire pitmen, and stories concerning the riots were still recalled in some mining communities over half a century later.

1 For a detailed account of the social deprivation experienced by Yorkshire miners and their families during the 1893 stoppage see Neville, op. cit., pp. 220 22. cf. Naylor, op. cit.; Yorkshi1e Evening Post, 12 December 1974. 